\begin{tabular}{lr}
\hline Jurnal Abdimas llmiah & JURNAL ABDIMAS ILMIAH CITRA BAKTI \\
Citra Bakti & Volume 2, Nomor 2, November 2021 \\
$(\mathrm{JAICB})$ & \\
\hline
\end{tabular}

\title{
SOSIALISASI DAN PENDAMPINGAN PENERAPAN POLA HIDUP BERSIH DAN SEHAT SEBAGAI UPAYA PENCEGAHAN COVID-19 DI DESA EKOROKA
}

\author{
Prisko Yanuarius Djawaria Pare ${ }^{1)}$, Maria Yuliana Kua ${ }^{2)}$, Fransiskus Xaverius Dolo ${ }^{3)}$ \\ Flora Plasinta Jaghung ${ }^{4)}$, Maria Esty Lelifanti ${ }^{5)}$ \\ 1,2,3,4)Program Studi Pendidikan IPA, STKIP Citra Bakti \\ 1)priskodjawaria@gmail.com, ${ }^{2}$ yulianakua03@1@gmail.com, \\ ${ }^{3)}$ dfransiskusxaverius@gmail.com, ${ }^{4)}$ floraplasintajaghung@gmail.com, ${ }^{5)}$ maria \\ lelifanti@gmail.com
}

\section{Histori artikel}

Received:

24 November 2021

Accepted:

29 November 2021

Published:

30 November 2021

\begin{abstract}
Abstrak
Tujuan kegiatan ini yakni memberikan sosialisasi dan pendampingan pola hidup bersih dan sehat (PHBS) sebagai upaya pencegahan COVID-19. Metode yang digunakan dalam pengabdian masyarakat ini berupa sosialisasi dan pendampingan penerapan PHBS yang dilakukan dalam tiga tahap yakni tahap pelaksanaan, persiapan dan evaluasi. Sasaran pelaksanaan kegiatan ini yaitu warga Desa Ekoroka. Hasil kegiatan ini adalah warga Desa Ekoroka mendapatkan pengetahuan melalui tahap sosialisasi berbasis teori mengenai cara mewaspadai dan menangani COVID-19, cara menerapkan pola hidup bersih dan sehat (PHBS) termasuk jenis-jenis makanan dan minuman yang sehat, cara menggunakan masker (dapat membedakan masker yang sekali pakai dan masker yang dapat di cuci ulang), serta cara mencuci tangan dengan baik dan benar. Berdasarkan hasil sosialisasi dan pendampingan tersebut, warga desa Ekoroka dapat mempraktikan pola hidup bersih dan sehat seperti cara mencuci tangan dengan baik dan benar, cara menggunakan masker (mengetahui jenis masker sekali pakai dan jenis masker cuci ulang), mematuhi protokol kesehatan, menerapkan pola dan perilaku hidup sehat di masyarakat dengan mengkonsumsi makanan sehat serta bergizi, dan berolah raga secara rutin.
\end{abstract}

Kata-kata Kunci: sosialisasi, pendampingan, pola hidup bersih dan sehat, COVID-19 
Abstract. The purpose of this community service is to provide socialization and assistance for a healty funded lifestyle as an effort to prevent covid-19. The method used in this community service is in the form of socialization and assistance based on the theory and practice of a clean and healty lifestyle as an effort to prevent covid-19 with there stages, namely the implementation stage, the preparation stage and the evaluation stage. The target of this community service activity is the residents of Ekoroka village. The results of Ekoroka village gain theoretical and practical knowledge about how to be aware of and deal with Covid-19, how to apply a healthy and clean lifestyle and drinks, how to use masks (can distinguish masks from other people). Disposable and reusable masks), how to wash your hands properly and correctly. From the results of the socialization and assistance, the residents ofo Ekoroka Village can practice a clean and healthy lifestyle such as how to use a mask (knowing the types of washing masks) avoiding direct contact with other residents, complying with health protocols, implementing healthy lifestyles and behaviors in the community by consuming healthy and nutritious food, exercising regularly. Carry out reutine health checks at the Nearest Health Service Center through a socialization-based phase.

Keywords: socialization, assistance, healthy and clean lifestyle, COVID-19

\section{PENDAHULUAN}

COVID-19 merupakan jenis virus yang dapat membuat sistem pernapasan terinfeksi (Li et al, 2020). Banyak kasus menunjukkan bahwa virus ini menyebabkan infeksi pernapasan ringan, namun dapat juga menyebabkan infeksi pernapasan berat. Gejala yang ditimbulkan oleh virus corona ditandai dengan gejala batuk kering, demam, flu serta lelah (World Health Organization, 2020). Wabah virus pertama kali terjadi di Ibukota China yakni Wuhan, kemudian menyebar ke berbagai Negara salah satunya Indonesia (Wen et al, 2020; Zhang et al, 2020). Hingga kini, melalui laporan tim Gugus Tugas Nasional tercatat 1,46 juta orang yang terpapar COVID-19 tertanggal 23 oktober 2021. Jumlah tersebut semakin mengalami kenaikan dari hari ke hari. Hal tersebut harus menjadi perhatian semua orang agar tetap waspada dan mulai memprioritaskan penerapan Pola Hidup Bersih dan Sehat (PHBS).

PHBS adalah singkatan dari pola hidup bersih dan sehat. PHBS merupakan segala perilaku sehat yang diterapkan oleh seseorang atau kelompok dengan penuh kesadaran sehingga seluruh anggota keluarganya mampu melakukan pertolongan secara mandiri (Ardiyanto et al, 2020). Menerapkan perilaku PHBS juga merupakan suatu upaya menjadikan anggota masyarakat sebagai agen perubahan supaya mampu meningkatkan kualitas diri dalam menerapkan PHBS.

Membiasakan pola hidup bersih dan sehat perlu diterapkan dari sekarang terlebih pada masa pandemi COVID-19 ini (Nailul, 2020; Kua, 2021). Pembiasaan PHBS bermaksud memberikan suatu aktivitas rutin pada seseorang terkait pola hidup bersih dan sehat sehingga menjadi suatu kebiasaan (Limbong et al, 2020). Peran orangtua sangatlah penting dan berpengaruh dalam pembiasaan berpola hidup bersih dan sehat di dalam keluarga. Orangtua berkewajiban dalam penentuan pilihan layanan kesehatan yang berkualitas untuk anggota keluarga seperti mengonsumsi berbagai jenis makanan yang sehat, dukungan emosional, kegiatan hidup sehari-hari (aktivitas fisik) serta kualitas lingkungan (Nurmahmudah, 2020). Oleh sebab itu, pembiasan pola hidup bersih dan sehat kepada anggota keluarga khususnya dan masyarakat di masa wabah virus corona ini dapat dilakukan baik itu berbasis teori 
maupun praktik secara langsung. Jika masyarakat membiasakan diri dalam menerapkan pola hidup bersih dan sehat, maka secara tidak langsung masyarakat telah berperan aktif dalam memerangi COVID-19 di Indonesia (Kurniawati, 2020).

Oleh karena itu, seharusnya masyarakat dapat menumbuhkan kesadaran diri untuk selalu menerapkan pola hidup bersih dan sehat. Namun, kesadaran diri di tengah-tengah masyarakat masih minim tak terkecuali masyarakat di Desa Ekoroka. Untuk itu pengabdian ini difokuskan pada pemberian edukasi kepada masyarakat terkait penerapan PHBS sebagai usaha mencegah COVID-19. Cara pembiasaan PHBS di masa pandemi COVID-19 dapat dilakukan dengan mengonsumsi makanan yang sehat berupa sayur-sayuran dan buahbuahan dan melakukan aktivitas fisik berupa olahraga (Safitri dan Harun, 2020). Pembiasaan pola hidup bersih dan sehat dapat diawali dengan aktivitas sederhana berupa menyikat gigi, mencuci tangan sebelum dan sesudah makan, mandi dua kali sehari, menggunakan air bersih, dan membuang sampah pada tempatnya (Yufiarti, 2019). .

Berdasarkan hasil survei pada warga Desa Ekoroka, tampak bahwa banyak warga belum memahami secara jelas mengenai virus corona atau COVID-19, cara mewaspadai, cara menangani, dan penerapan PHBS. Hasil observasi inilah yang mendasari dilakukannya kegiatan pengabdian masyarakat ini. Kegiatan dilakukan dalam bentuk edukasi yang diawali dengan sosialisasi kepada masyarakat desa Ekoroka mengenai apa itu PHBS dan bagaiamana menerapkannya serta dilanjutkan dengan proses pendampingan oleh tim Abdimas terkait cara menerapkan PHBS di tengah situasi pandemi COVID-19 sebagai salah satu upaya dalam pencegahannya.

\section{METODE PELAKSANAAN}

Pelaksanaan kegiatan pengabdian masyarakat terhadap upaya pencegahan COVID19 melalui pola hidup bersih dan sehat ini terdiri dari beberapa tahapan yaitu:

\section{Tahap Persiapan}

Pada tahap ini tim Abdimas mengunjungi lokasi untuk melakukan observasi terkait sejauh mana kesiapan warga dalam upaya pencegahan COVID-19. Selain itu, tim juga mengobservasi profil Desa ekoroka dan mempersiapkan berbagai sarana serta prasarana yang akan dibutuhkan dalam kegiatan PkM tersebut.

2. Tahap Pelaksanaan

Pemberian edukasi berupa sosialisasi terkait penerapan PHBS sebagai upaya pencegahan COVID-19 dilakukan dengan tatap muka secara terbatas di kantor desa Ekoroka yang dihadiri oleh perwakilan masing-masing keluarga. Kegiatan dilakukan dengan selalu memperhatikan dan menerapkan protokol kesehatan. Materi yang diberikan diantaranya adalah apa itu COVID- 19, cara melakukan pencegahan penyebaran COVID-19, apa itu 
PHBS, serta bagaimana cara menerapkan PHBS. Selain itu, tim juga memberikan edukasi dengan konsep door to door serta poster.

3. Tahap evaluasi

Pada tahap evaluasi ini, tim Abdimas mengevaluasi pemahaman para warga desa ekoroka dengan memberikan sejumlah pertanyaan terkait penerapan PHBS sebagai upaya mencegah penyebaran COVID-19.

\section{HASIL DAN PEMBAHASAN}

Desa Ekoroka merupakan salah satu desa di Kecamatan golewa, Kabupaten Ngada yang masih berstatus desa berkembang. Hasil dari pelaksanaan kegiatan PkM ini dibagi ke dalam 3 kegiatan, yakni

1. Tahap Persiapan

Pada tahap ini tim Abdimas melakukan observasi pada desa sasaran kegiatan. Tujuan dari observasi ini, yakni melihat dan melakukan pengecekan kondisi warga Desa ekoroka. Hasil dari observasi tersebut dapat diketahui status sosial, profesi, umur, latar belakang pendidikan, ekonomi, sosial, dan budaya. Bertolak dari informasi yang diperoleh, tim Abdimas kemudian menetapkan pendekatan dalam memberikan edukasi berupa teori dan praktik terkait cara mewaspadai COVID-19, cara menangani COVID-19, cara menerapkan PHBS termasuk jenis makanan dan minuman yang sehat, cara menggunakan masker (cara membedakan masker yang sekali pakai dan masker yang dapat dicuci ulang), serta cara mencuci tangan dengan baik dan benar. Setelah pendekatan edukasi dipilih, selanjutnya tim Abdimas menyiapkan sarana dan prasarana pendukung pelaksanaan pengabdian.

2. Tahap pelaksanaan

Pada tahap pelaksanaan yang dilakukan pertama adalah edukasi berupa sosilasisasi mengenai apa itu COVID-19, cara mewaspadai COVID-19, cara-cara menangani COVID-19, cara menerapkan PHBS yang didalamnya termasuk jenis-jenis makanan dan minuman yang sehat, cara menggunakan masker (cara membedakan masker yang sekali pakai dan masker yang dapat dicuci ulang), serta cara mencuci tangan dengan baik dan benar. Tim juga memberikan edukasi terkait pembuatan sabun cair untuk cuci tangan, hand sanitizer, serta cairan disinfektan. Tim menggunakan beberapa jalur edukasi di antaranya komunikasi langsung secara tatap muka dalam kelompok terbatas yang bertempat di kantor desa Ekoroka, jalur door to door dengan mendatangi rumahrumah warga guna memberikan edukasi mandiri kepada anggota keluarga sehingga informasi yang diberikan lebih terfokus pada masing-masing keluarga dan disesuaikan dengan permasalahan masing-masing, serta jalur media dalam bentuk poster yang ditempelkan pada public area atau pada dinding rumah warga yang mudah terlihat. 
Materi edukasi terkait cara mewaspadai dan menangani COVID-19 yang diutarakan oleh tim Abdimas seperti:

1) Apa itu COVID-19, apa gejala yang timbul pada seseorang yang dinyatakan positif, dan bagaimana cara penularannya.

2) Cara menggunakan masker

Masker merupakan salah satu alat pelindung diri khususnya dalam mencegah terinfeksi dari COVID-19 oleh karena itu tim Abdimas menegaskan cara penggunaan masker yang benar.

3) Cara mencuci tangan

Salah satu kasus penularan virus diprediksi terjadi ketika tangan menyentuh permukaan atau wadah yang terkontaminasi virus lalu tidak sengaja memegang wajah. Lalu virus tersebut berpindah dari tangan ke hidung atau mulut. Oleh karena itu, ditekankan kepada seluruh warga agar membiasakan diri mencuci tangan dengan sabun dan sedapat mungkin untuk tidak menyentuh wajah ketika habis menyentuh sebuah benda atau wadah.

4) Penggunaan healthy kit seperti hand sanitizer, cairan disinfektan, tisu basah, tisu kering, dan vitamin. Tim Abdimas juga menjelaskan cara membuat hand sanitizer dan cairan disinfektan dengan menggunakan produk rumah tangga dan dapat dilakukan secara mandiri dan aman di rumah.

5) Social Distancing

Social distancing adalah suatu langkah pencegahan dan pengendalian terhadap COVID-19 agar tidak terinfeksi, slah satunya, yakni dengan membatasi kunjungan ke tempat-tempat ramai serta berkontak langsung dengan orang sekitar. Saat menerapkan social distancing harus menjaga jarak sekitar 1 meter dalam berinteraksi, khususnya dengan orang yang sedang sakit atau penderita COVID-19.

6) Apa itu PHBS dan bagaimana penerapannya.

7) Peningikatan imun tubuh melalui Istrahat cukup dan makanan yang sehat Istrahat yang cukup dan mengonsumsi makanan bergizi salah satu cara meningkatkan imun tubuh sehingga mencegah COVID-19. Kondisi imun yang bagus dapat memengaruhi kondisi tubuh dalam menangkal virus. Orang yang terinfekai COVID-19 tidak serta merta meninggal dunia tetapi karena kondisi imunnya dan penerapan PHBS-nya yang cukup baik maka berhasil sembuh. Oleh karena itu sangat penting untuk makan makanan yang bergizi dan istirahat yang cukup

\section{Tahap Evaluasi}

Pada tahap evaluasi ini, tim Abdimas memberikan sejumlah pertanyaan terkait materi-materi yang telah diberikan oleh tim selama kegiatan pengabdian berlangsung. Tim mendapatkan jawaban yang baik dari warga desa Ekoroka. Hal ini menunjukkan tingkat 
pemahaman yang baik atas kegiatan yang diikuti oleh masyarakat dalam bentuk sosialisasi dan pendampingan penerapan PHBS.

Selain itu, kegiatan yang dilakukan oleh tim Abdimas mendapatkan respon positif oleh warga Desa ekoroka. Hal ini terlihat dari adanya sabun cair cuci tangan yang dibuat sendiri oleh masyarakat dan ditempatkan di depan rumah bersama tempat cuci tangan. Selain itu masyarakat juga mulai membiasakan menggunakan cairan disinfektan dan hand sanitizer yang merupakan buatan sendiri. Hasil dari pengabdian ini adalah masyarakat memperoleh tambahan pengetahuan, informasi, dan peningkatan pemahaman dalam menghadapi penyebaran COVID-19 melalui penerapan PHBS dalam kehidupan sehari-hari dalam keluarga.
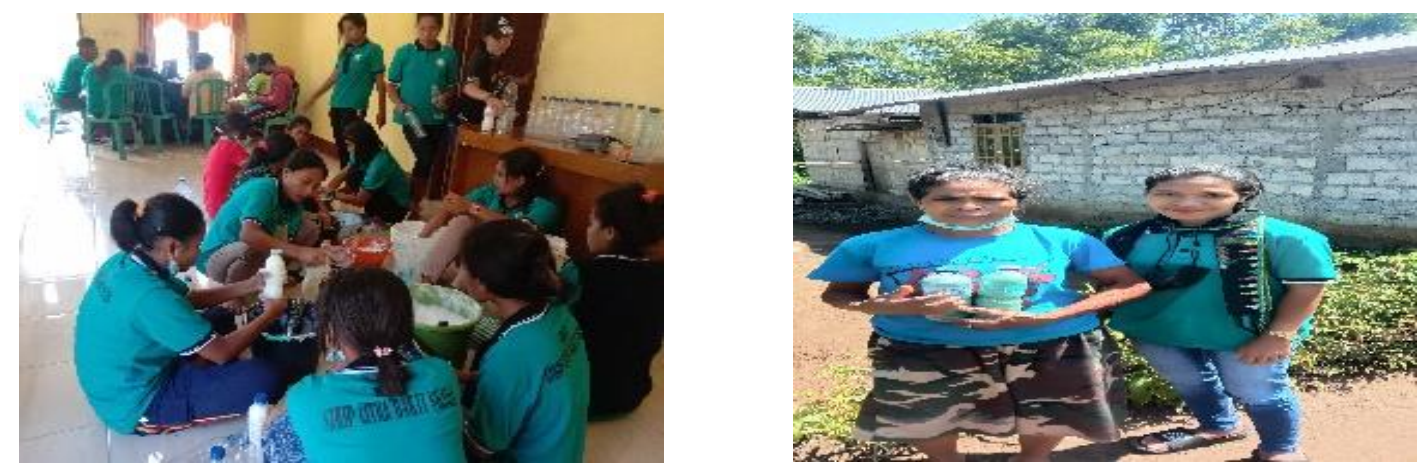

Gambar 1. Tim bersama masyarakat dalam praktik membuat sabun cuci tangan.

\section{KESIMPULAN}

Berdasarkan pelaksanaan PkM terkait sosialisasi dan pendampingan penerapan pola hidupa bersih dan sehat sebagai upaya pencegahan penyebaran COVID-19 di desa Ekoroka, Kabupaten Ngada, warga Desa ekoroka dapat memahami apa itu COVID-19, gejala, penularan dan pencegahannya dengan mempraktikkan PHBS seperti cara mencuci tangan dengan baik dan benar, cara menggunakan masker yang baik dan benar, menghindari kontak langsung dengan warga lain, mematuhi protokol kesehatan, dan menerapkan pola hidup sehat di masyarakat dengan mengkonsumsi makanan sehat yang bergizi, serta berolah raga secara rutin.

\section{DAFTAR PUSTAKA}

Ardiyanto, A., Purnamasari, V., Sukamto, \& Eka Sari S. (2020). Analisis Perilaku Hidup, Bersih dan Sehat di Era Pandemi Covid-19 Dosen PGSD. Jendela Olahraga, 05(02), 131-140.

Kua. (2021). Edukasi Pencegahan Covid-19 Melalui Pendampingan Pembuatan Serta Penggunaan Healthy KIT Produksi Lokal Rumah Tangga. Jurnal Masyarakat Mandiri (JMM), 5 (1), 1-11. 
Kurniawati, K. R. A., Santosa., Farah., Heniati., \& Bahri, S. (2020). Sosialisasi Hidup Sehat di Tengah Wabah Virus Corona. JPMB: Jurnal Pemberdayaan Masyarakat Berkarakter, 3(1), 58-65.

Li, Q., Tong, Y., Ph, D., Ren, R., Med, M., Leung, K. S. M., Ph, D., Lau, E. H. Y., Ph, D., Wong, J. Y., Ph, D., Xing, X., Ph, D., Xiang, N., Med, M., Wu, Y., Sc, M., Li, C., Chen, Q., ... Med, M. (2020). Early Transmission Dynamics in Wuhan, Shina, of Novel CoronavirusInfevted Pneumonia. New England Journal of Medicine, 382(13), 1199-1207. https://doi.org/10.1056/NEJMoa2001316

Limbong, W. S., Girsang, M. L., \& Ruth Donda Panggabean. (2020). Sosialisasi Gaya Hidup Sehat Pada Masa Pandemi Covid-19 di Panti Asuhan Talenta Delpita Di Medan. Abdimas Mutiara, 1(2), 199-205.

Nailul, M. (2020). Konsep Isolasi Dalam Jaringan Sosial Untuk Meminimalisasi Efek Contagious (Kasus Penyebaran Virus Corona Di Indonesia). Jurnal Sosial Humaniora Terapan, 2(2), 117-125.

Nurmahmudah, E., Puspitasari, T., \& Agustin, I. T. (2018). Perilaku hidup bersih dan sehat (PHBS) pada anak sekolah. ABDIMAS: Jurnal Pengabdian Masyarakat, 1(2), 46-52.

Safitri, H. I., \& Harun. (2021). Membiasakan Pola Hidup Sehat dan Bersih pada Anak Usia Dini Selama Pandemi Covid-19. Obsesi, 5(1), 385-394.

Susiati, S., Tahir, S. Z. B., Hajar, I., \& Tenriawali, A. Y. (2021). Optimalisasi Masyarakat Desa Namlea Dalam Menghadapi Tanggap Darurat Pandemi Covid-19. Journal of Community Dedication and Development (Pengabdian Kepada Masyarakat), 1(1), 50-59.

Yufiarti, Y., Edwita, \& Suharti. (2019). Healt Promotion Program (JUMSIH); To Enhance Children's Clean and Healthy Living Knowledge. Pendidikan Usia Dini, 13(2), 341-355.

Wen, J., Cheng, Y., Ling, R., Dai, Y., Huang, B., Huang, W., ..., \& Jiang, Y. (2020). International Journal of Infectious Diseases Antibody-Dependent Enhancement of Coronavirus. International Journal of Infectious Diseases, 100(1), 483-489. https://doi.org/10.1016/i.ijid.2020.09.015

World Health Organization. (2020). Coronavirus Disease (COVID-19) Advice for the Public. Diterima pada 29 April 2020 melalui www.who.int.

Zhang, M., Zhou, M., Tang, F., Wang, Y., Nie, H., Zhang, L., \& You, G. (2020). Knowledge, attitude, and practice regarding COVID-19 among healthcare workers in Henan, China. Journal of Hospital Infection, 105(2), 183-187. https://doi.org/10.1016/j.jhin.2020.04.012 